\title{
A NEW SMALL-FLOWERED CYRTOCHILUM SPECIES (ORCHIDACEAE: ONCIDIINAE) FROM THE CONDOR MOUNTAINS IN ECUADOR
}

\author{
Stig Dalström ${ }^{1,3} \&$ Wesley Higgins ${ }^{2}$
}

\author{
12304 Ringling Boulevard, unit 119, Sarasota FL 34237, U.S.A.; Lankester Botanical Garden, \\ University of Costa Rica, Cartago, Costa Rica; National Biodiversity Centre, Serbithang, Bhutan \\ 25317 Delano Ct, Cape Coral, FL 33904, U.S.A; Lakes Park Botanic Garden, Fort Myers, Florida, \\ U.S.A.; American Orchid Society, P.O. Box 565477, Miami, FL 33256-5477, U.S.A. \\ ${ }^{3}$ Corresponding author: stigdalstrom@gmail.com
}

\begin{abstract}
A new small-flowered species of Cyrtochilum from the isolated range of the Condor mountains in Ecuador is described and illustrated with a line drawing and a photograph of the holotype. It shares morphological features with several different-looking groups of Cyrtochilum, such as the two generitypes of the genus: $C$. undulatum and C. flexuosum, as well as with plants in the C. myanthum complex. These groups are treated as three separate genera by some (Cyrtochilum, Trigonochilum and Dasyglossum, respectively), but the combination of morphological features seen in our new species brings the groups together into one polymorphic but genetically monophyletic genus.
\end{abstract}

Key Words: Condor, Cyrtochilum, new species, Oncidiinae

Introduction. The genus Cyrtochilum Kunth was originally placed between Oncidium Sw., and Epidendrum L., from which it was distinguished by features such as unguiculate sepals and petals, and a shortened spur-less convex lip, hence the name of the genus (Kunth 1816). These generic delineations were based on two species; Cyrtochilum undulatum Kunth (Fig. 1) and C. flexuosum Kunth (Fig. 2) and may have appeared sufficient in 1815. With time, however, many new species were discovered and described, and it became more and more difficult to delineate Cyrtochilum from particularly Oncidium and Odontoglossum Kunth (Lindley 1833). As a result, a considerable confusion and disagreement developed among taxonomists how to treat this large group of plants (Lindley 1838, 1841, 1852, 1855, Reichenbach 1849, 1854, Beer 1854, Rolfe 1896,Kränzlin 1917,1922, Schlechter 1924, Garay 1970, Bockemühl 1989, Königer 1991, 1996, Königer \& Schildhauer 1994, Senghas 1994, 1997, Dalström 2001, Szlachetko et al. 2017), which continue to this day. Part of the reason for this controversy is the natural variation of species within this large complex of plants, and partially depending on the taxonomists' preference for large or small genera and specifically what features to base them on. The relatively recent arrival of molecular research, particularly DNA sequencing, has helped the plant systematists to better understand how taxa are related to each other, but it has not solved the challenge of how to organize them in practical, user-friendly and visually distinguishable systems. This task is still up to the taxonomists.

Basically there are two main alternatives available how to handle this situation. Do we classify taxa according to how closely they are genetically related to each other? Or do we classify taxa based on how closely the flowers (generally) look like each other? The former method is a modern version which is strictly preferred by some, while the latter method is the older and traditional method preferred by others. The authors of this paper prefer using a combination of both methods in addition to any other informative data that can be accumulated. Combining the two methods must be done in a certain order though. The foundation of modern classification should primarily be based on molecular evidence from correctly identified voucher specimens (which are not always the case) that show natural and biological relationships between taxa. This is important in order to better understand the evolutionary processes that drive the creation of new taxa. Once we have a better understanding of how the various members of the Cyrtochilum-OncidiumOdontoglossum (C-O-O) complex, for example, are related to each other, we can begin using morphological features in order to find a way to visually distinguish them from each other and to place them in natural 


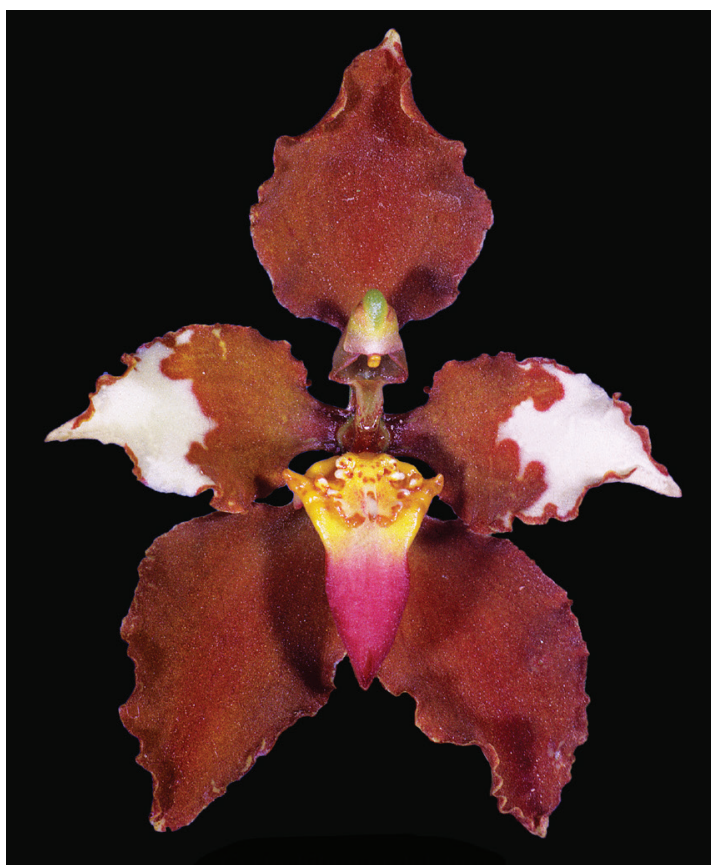

FIGURE 1. Cyrtochilum undulatum (syn. C. ventilabrum

(Rchb.f.) Kraenzl.), one of two generitypes for the genus. Photo by G. Escobar \# 433. groups. This method will create visually identifiable monophyletic genera, meaning that all species in each group/clade/branch have evolved from the same ancestor. At the same time this presents natural groups of plants that share certain features that visually distinguish them from other groups. But this method has some challenges as well. Nature follows its own rules, which sometimes can appear whimsical and frequently allows not closely related plants to develop flowers that look similar because they target the same pollinators. Similarly, plants that are closely related and grow together may display very different-looking flowers because they are targeting different pollinators. When we place species together based on floral similarities alone without respecting the genetic background, we risk creating polyphyletic groups with ancestors that come from unrelated backgrounds. This has happened a lot within the C-O-O complex and is a major reason why there are still considerable disagreements among taxonomists about how to treat this group. To include some complexes of plants that molecular evidence show belong together in a monophyletic Cyrtochilum (Williams et al. 2001, Pridgeon et al. 2009, Szlachetko

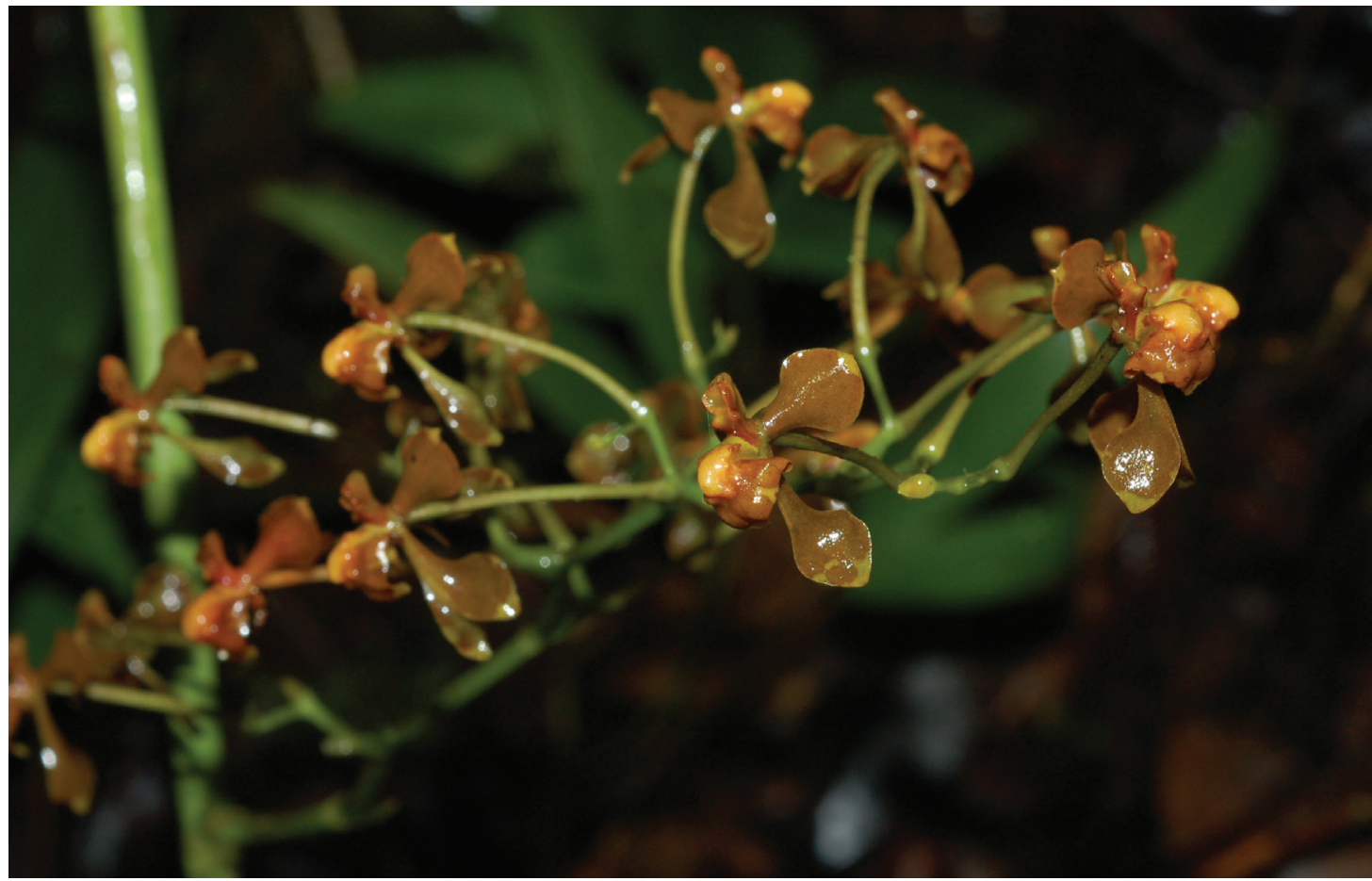

FIGURE 2. Cyrtochilum flexuosum, from Cali in Colombia, the second of the two generitypes for the genus. Photo by Stig Dalström. 
et al. 2017) for example, but exclude the closely related C. pardinum Lindl., and C. ramosissimum (Lindl.) Dalström complexes, which also belong in the same monophyletic Cyrtochilum, and move them into the distantly related Odontoglossum based on floral similarities alone (Szlachetko et al. 2017) is inconsistent with the principles of monophyletic genera and is not accepted by us. We, therefore, prefer to maintain Cyrtochilum as circumscribed by Dalström (2001), by Williams et al. (2001), and by Pridgeon et al. (2009), and keep the various branches of this florally polymorphic but vegetative rather similar and monophyletic complex of species together under one admittedly wide umbrella. This directs us to describe the following taxon as a new species of Cyrtochilum.

\section{TAXONOMIC TREATMENT}

\section{Cyrtochilum gentryi Dalström \& W.E.Higgins, sp. nov.} (Figs. 3-4).

TYPE: Ecuador. Morona-Santiago: Gualaquiza; Campamento Achupalla, Cordillera del Cóndor, 15 $\mathrm{km}$ east of Gualaquiza, tepui-like bromeliad sward with scattered small trees, $\mathrm{S} 03^{\circ} 27^{\prime} ; \mathrm{W} 78^{\circ} 22^{\prime}$, altitude 2090 m, 21 July, 1993, A. Gentry 80304 (holotype: SEL, isotype MO).

Diagnosis: Cyrtochilum gentryi is distinguished from all other small-flowered Cyrtochilum species by the combination of features such as a creeping habit similar to species in the C. undulatum, C. flexuosum and C. auropurpureum (Rchb.f.) Dalström complexes, a straight column that is parallel with the base of the lip as for species in the C. myanthum complex (Fig. 5), and a pollinarium where the stipe has a well developed extension between the pollinia, as in the C. cimiciferum (Rchb.f.) Dalström complex, and from all other smallflowered Cyrtochilum species by the structure of the interior pair of extended brachiate, or arm-like, lobes below the stigmatic surface.

Terrestrial herb. Roots few and scattered on a climbing ca. $5 \mathrm{~mm}$ thick, bracteate rhizome. Pseudobulbs distinctly distant, ovoid elongate, $c a .2 .5$ $\times 1.0 \mathrm{~cm}$, unifoliate, surrounded basally and mostly hidden by 5-6 distichous foliaceous sheaths. Leaves subpetiolate with an abscission layer $c a .1 \mathrm{~cm}$ from the apex of the pseudobulb, conduplicate, lanceolate, narrowly acute and sub-apiculate, 5.5-5.8 $\times 1.8 \mathrm{~cm}$. Inflorescence axillary from the base of the pseudobulb, 1 or 2 , erect from a developing growth, to $c a .37 \mathrm{~cm}$ or taller, straight peduncle, with a fractiflex $3.5-6.0 \mathrm{~cm}$ long raceme or panicle with widely spaced, indistinctly flexuous side-branches (the multiple inflorescences on the type specimen are cut up, which makes it difficult to see which part is the extension of which other part). Peduncular bracts scale-like, appressed, acute, ca. $5 \mathrm{~mm}$ long; floral bracts similar, 1.5-3.0 mm long. Pedicel with ovary 10-17 mm long. Flowers dark brown with a yellow lip. Dorsal sepal sub-unguiculate, obovate, indistinctly canaliculated near the base, then cupulate, obtuse, sub-apiculate with 3 main veins, $c a$. $7.0 \times 3.5 \mathrm{~mm}$ when flattened. Lateral sepals fused basally to each other and to the short column foot for $c a .2 .5 \mathrm{~mm}$, then spreading, unguiculate, elliptic to indistinctly obovate and indistinctly oblique, indistinctly canaliculated apically, bluntly apiculate, with 3 main veins, $c a .8 .5-9.0 \times 3 \mathrm{~mm}$. Petals subsessile, distinctly obliquely basally, then narrowly elliptic to almost linear, obtuse and apiculate, $c a$. 7.0 $7.1 \times 3 \mathrm{~mm}$, with 3 main veins. Lip rigidly attached to the base and along the margin of the $c a .1 .5-2.0$ $\mathrm{mm}$ long column foot, hastate to indistinctly cordate, trilobate with broadly orbiculate, entire and probably spreading lateral lobes, and a cupulate, rounded, entire front lobe, $c a$. $6.0-6.5 \times 5 \mathrm{~mm}$ when flattened; callus is a fleshy, elevated central hump emerging at the base of the lip and extending for $c a .1 .2 \mathrm{~mm}$, then developing into a raised longitudinal pair of $c a .3 .3$ $\mathrm{mm}$ long, parallel, fleshy ridges that diverge apically into rounded angles. Column stout, slightly up-curved ("sway-backed") ventrally deeply concave between the lateral, slightly rounded flanks, ending with a blunt, sub-rectangular lobe, with an additional interior pair of brachiate lobes below the stigmatic surface, $c a .4$ mm long. Anther cap campanulate and verruculose, shortly rostrate with a dorsal ridge. Pollinarium of two obovoid, cleft/folded, micro-verruculose pollinia on a minute, folded (on the rehydrated specimen) subtriangular stipe, with a digitate extension between the pollinia (viscidium not seen).

Paratype: No additional material seen.

Distribution: Cyrtochilum gentryi is only known from the type location, at $c a$. 2000-2100 m elevation 


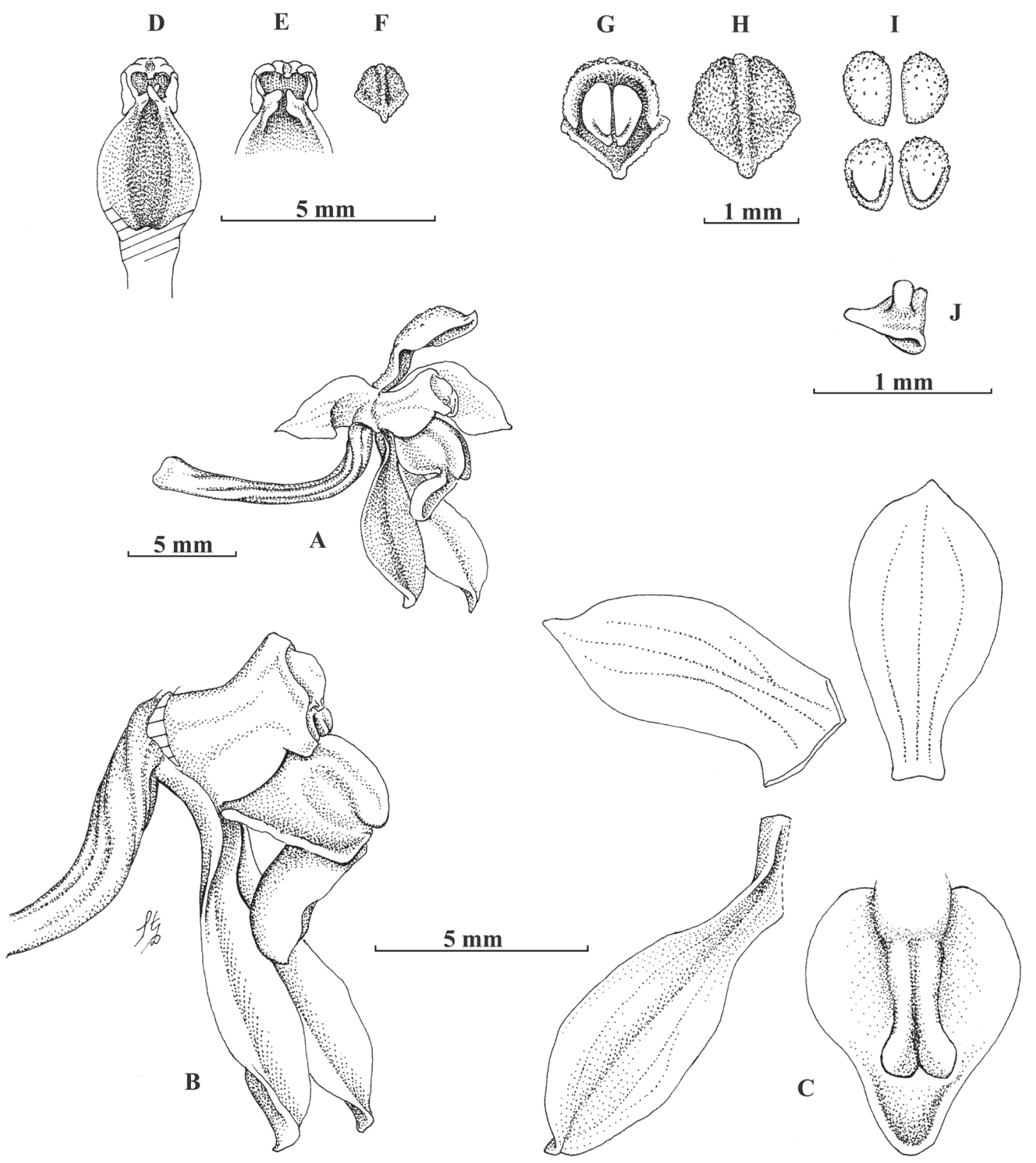

Figure 3. Cyrtochilum gentryi Dalström \& W.E.Higgins. A. Gentry 80304 (holotype: SEL, isotype: MO). A. Flower lateral view. B. Column, lip and lateral sepals lateral view. C. Dissected flower. D. Column ventral view. E. Column slightly widened, ventral view. F. Anther cap front view. G. Anther cap with pollinia, ventral view. H. Anther cap front view. I. Pollinia front and back views. J. Stipe without viscidium, tilted left, lateral view. Drawn from the holotype by Stig Dalström.

$\rightarrow$ Right, Figure 4. Cyrtochilum gentryi. Holotype specimen A. Gentry 80304 at SEL. Photo by Stig Dalström. 


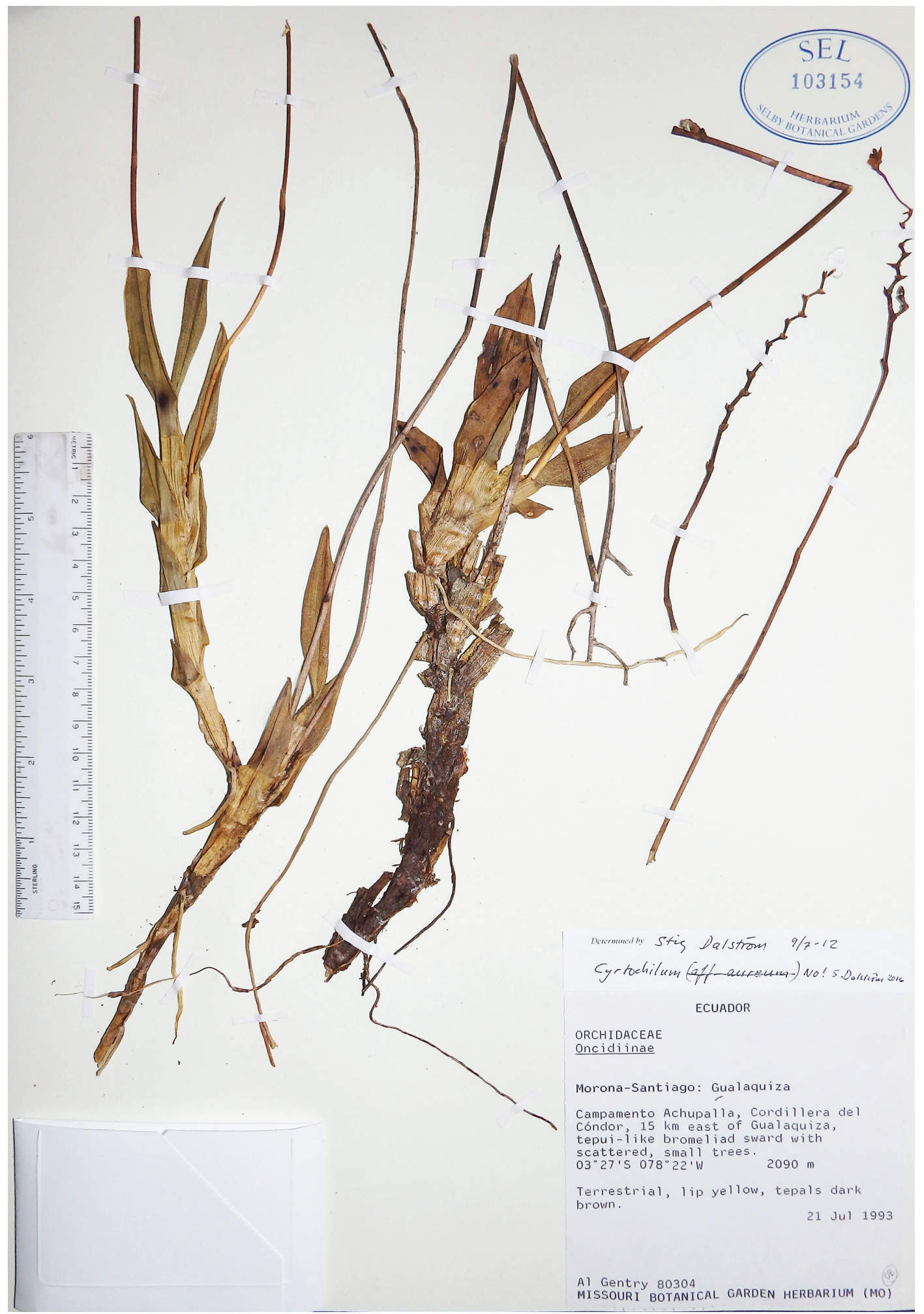




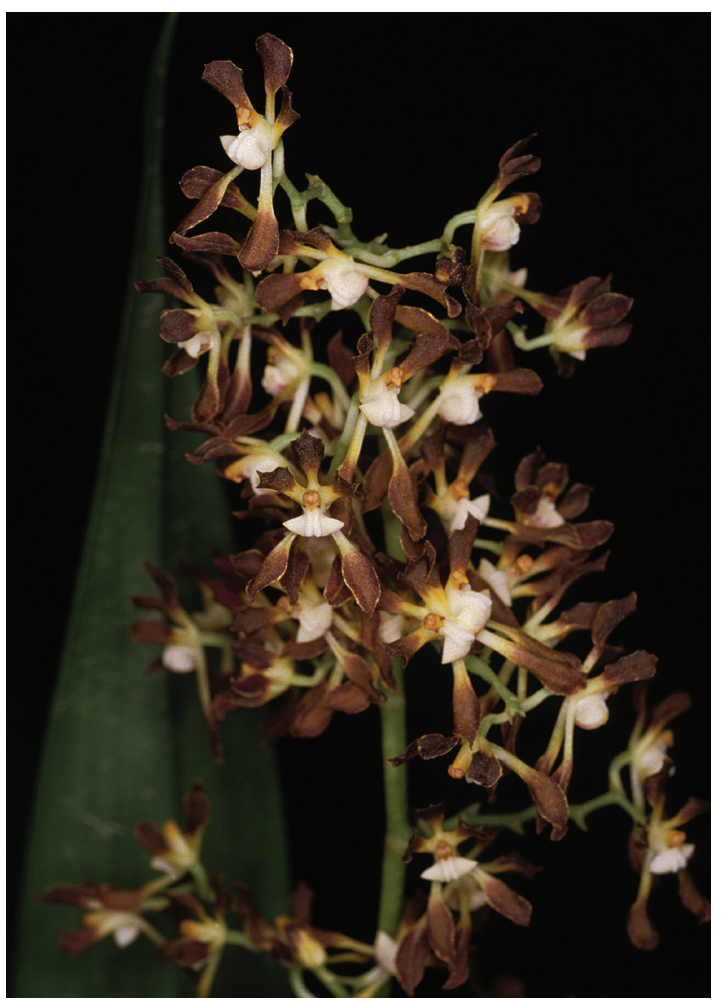

Figure 5. Cyrtochilum myanthum, from Ecuador. Photo by Stig Dalström. on the upper plateau of the Cordillera del Cóndor in Ecuador (Fig. 6), growing terrestrially in a "tepui-like bromeliad sward with scattered small trees".

Eponymy: Named in honor of Alwyn Howard Gentry (1945-1993), a most prolific and dedicated botanist who died in an airplane crash near Guayaquil in Ecuador while working on a Rapid Assessment Program (Miller et al. 1996).

Discussion. Cyrtochilum gentryi is a very interesting species that share morphological features from several different species complexes in the genus, which have been treated as separate genera by some (Königer \& Schildhauer 1994, Königer 1996, Senghas 1997, Szlachetko et al. 2017). The growth habit with a creeping and bracteate rhizome is similar to that of species in the C. undulatum and C. flexuosum (the latter as genus Trigonochilum Königer \& Schildh.) complexes, thus displaying typical Cyrtochilum sensu stricto features (Kunth 1816), but also to the $C$. auropurpureum complex (genus Odontoglossum fide Bockemühl 1989, Szlachetko et al. 2017). The flower of C. gentryi, on the other hand, is morphologically close to those in the C. myanthum complex (genus Dasyglossum Königer \& Schildh.) with a column that

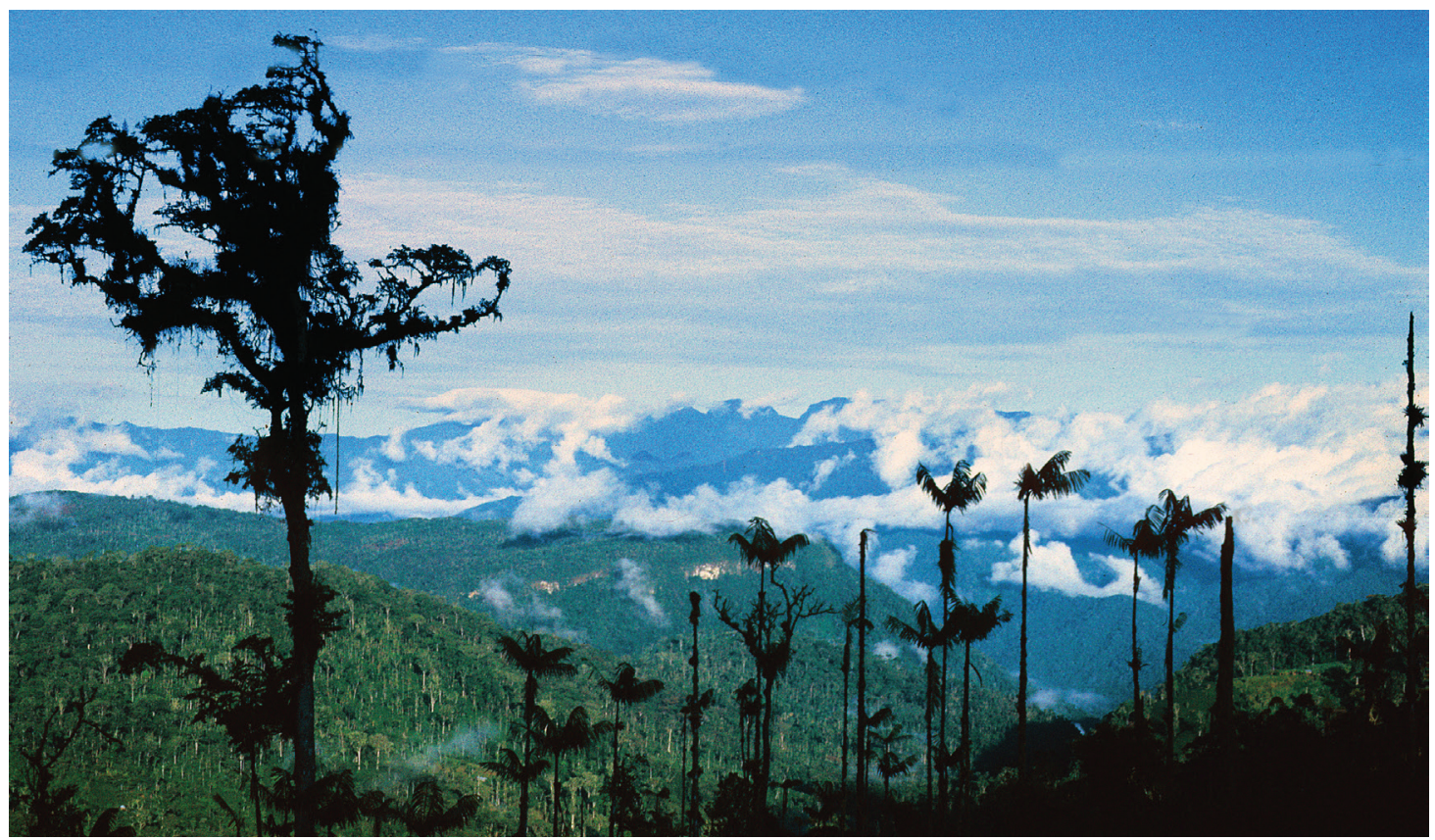

FIGURE 6. The isolated Condor mountain range in Ecuador, as seen from a position near the town of Gualaquiza. Photo by Stig Dalström. 
is more or less parallel with the base of the lip, and a lip callus consisting of a central pair of fleshy ridges that diverge apically. But the most intriguing feature can be seen in the pollinarium where the stipe has a distinct extension developed between the pollinia, similar to those in the $C$. cimiciferum complex (genus Trigonochilum Königer \& Schildh.): C. cimiciferum (Rchb.f.) Dalström, C. meirax (Rchb.f.) Dalström, C. midas Dalström, C. ovatilabium C.Schweinf., C. tricornis Dalström \& Ruíz-Pérez, C. tricostatum Kränzlin and C. williamsianum (Dodson) Dalström, and to a lesser extent to C. flexuosum. The distinct arm-like lobes, or extensions, below the stigmatic surface is very unusual, however, if not unique in the genus and readily distinguish this species. It seems risky to draw too many conclusions from this mixture of "generic possibilities" other than that it suggests a closer relationship with the $C$. flexuosum complex based on the vegetative and the micro-morphological features rather than to the C. myanthum complex despite the confusingly similar flowers. The "mixed" morphological features of $C$. gentryi also demonstrate the fragility of basing generic distinctions solely on morphological features. This further strengthens the preference for a broad generic concept in the case of Cyrtochilum.

ACKNOWLEDGMENTS. We thank the administration and staff of the Marie Selby Botanical Gardens (SEL) for allowing access to their collections and permitting using a photograph of the holotype for this article.

\section{LITERATURE CITED}

Beer, J. G. (1854). Praktische studien an der familie der orchideen. Vienna, Austria: Verlag und Druck von Carl Gerold \& Sohn.

Bockemühl, L. (1989). Odontoglossum, monographie und ikonographie - a monograph and iconograph. Germany: BrückeVerlag Kurt Schmersow.

Dalström, S. (2001). A synopsis of the genus Cyrtochilum (Orchidaceae; Oncidiinae): Taxonomic reevaluation and new combinations. Lindleyana, 16(2), 56-80.

Garay, L. (1970). A reappraisal of the genus Oncidium. Taxon, 19, 443-467.

Kränzlin, F. (1917). Cyrtochilum H.B.K. Notizblatt des königl. botanischen garten und museums zu Berlin, 63, 81-101.

Kränzlin, F. (1922). Orchidaceae-Monandrae, tribus Oncidiinae - Odontoglossae Pars II. In: H. G. A. Engler (Ed.), Das pflanzenreich, IV. 50 (80). Leipzig, Germany: Verlag von Wilhelm Engelmann.

Kunth, K. S. (1816). Cyrtochilum. In: A. von Humboldt, A. Bonpland \& K. S. Kunth, (Ed.). Nova Genera et Species Plantarum (349-350). Paris, France: A la librarie Grecque-Latine-Allemande, Rue de Fossés-Montmarte, No 14.

Königer, W. (1991). Cyrtochilum geniculatum — eine neue Art aus Ecuador. Orchidee (Hamburg), 42, 134-138.

Königer, W. (1996). Dasyglossum (Addenda \& corrigenda). Arcula, 5, 152-153.

Königer, W. \& Schildhauer, H. (1994). Dasyglossum and Trigonochilum - two new genera in subtribus Oncidiinae. Arcula, $1,5,13$.

Lindley, J. (1833). Cyrtochilum. The genera and species of orchidaceous plants (pp. 210-211). U.K.: Hunneman and Ridgways.

Lindley, J. (1838). Sertum orchidaceum. London, U.K.: Ridgways \& Sons.

Lindley, J. (1841). Sertum orchidaceum. London, U.K.: Ridgways \& Sons.

Lindley, J. (1852). Odontoglossum. Part 1. Folia orchidacea (pp. 1-24). London, U.K.: J. Mathews.

Lindley, J. (1855). Oncidium. Parts 6 \& 7. Folia orchidaceae (pp. 1-61). London, U.K.: J. Mathews.

Miller, J., Barkley, T., Iltis, H., Lewis, W., Forero, E., Plotkin, M., Phillips, O., Rueda, R. \& Raven, P. (1996). Alwyn Howard Gentry, 1945-1993: A Tribute. Annals of the Missouri Botanical Garden, 83(4), 433-460.

Pridgeon, A. M., Cribb, P. J., Chase, M. W. \& Rasmussen, F. N. (2009). Genera Orchidacearum 5, Epidendroideae (Part two). U.K.: Oxford University Press.

Reichenbach, H. G. fil. (1849). Beiträge zu einer Aequinoctialflor Amerika's. Linnaea, 22, 809-867.

Reichenbach, H. G. fil. (1854). Julius von Warszewicz; Orchideae Warszewiczianae recentiores. Bonplandia, 2, 95-102.

Rolfe, R. A. (1896). Rusbyella Rolfe, $n$. gen. Memoirs of the Torrey botanical club, 6, 122-123.

Schlechter, R. (1924). Beiträge zur Orchideenkunde von Colombia. Repertorium specierum novarum regni vegetabilis, beihefte, 27, 1-183. 
Senghas, K. (1994). Neue Kleinorchideen as Südamerika. Journal für den orchideenfreund, 1, 165 -197.

Senghas, K. (1997). Cyrtochilum. Trigonochilum. Schlechter, Die orchideen, 76, 2200-2216.

Szlachetko, D. L., Kolanowska, M., Naczk, A., Górniak, M., Dudek, M., Rutkowski, P. \& Chiron, G. (2017). Taxonomy of Cyrtochilum-alliance (Orchidaceae) in the light of molecular and morphological data. Botanical studies, 58, 8 .

Williams, N. H., Chase, M. W., Fulcher, T. \& Whitten, W. M. (2001). Molecular systematics of the Oncidiinae based on evidence from four DNA regions: expanded circumscriptions of Cyrtochilum, Erycina, Otoglossum and Trichocentrum and a new genus (Orchidaceae) Lindleyana, 16, 113-139. 